UDC 332.2

\title{
LEGISLATIVE ADMINISTRATION OF PUBLIC AFFAIRS AID IN THE FIELD OF HUMAN CONSUMPTION AS THE INSTRUMENT OF THE STATE POLICY
}

\author{
L. Demydenko, Postgraduate Student, \\ State Ecology Academy of Postgraduate Education and Management, \\ Ministry of Ecology and Natural Resources of Ukraine \\ E-mail: larysademydenko@gmail.com
}

The article analyzes normative documents according to which economic incentives can become state aid, ways of developing European and national policies that allow the allocation of state aid for environmental protection and protected areas, and the promotion of biodiversity conservation on legal grounds.

Keywords. State aid, environmental land use, ecological tax, biodiversity conservation, protected areas.

\section{Analysis of recent research and publications.}

The system of economic instruments and the application of the principles of economic ecological theory in Ukraine were studied: O.E. Rubel, V.A. Tolkachov, O.M. Kolosok and others. The development and ways of improving the system of protected land use are explored in thier works AM Tretyak, N.A.Tretyak. At the same time, the latest changes in the structure of the legislative field, adaptation to the European model of ecological and economic instruments for biodiversity conservation and support for environmental land use require the development of new approaches to the use of market and non-market mechanisms for economic stimulation of environmental protection measures.

The purpose of the article is to consider a set of environmental policy instruments to review the relevance of state aid rules for economic instruments and their role in implementing environmental policies.

\section{Presenting main material.}

As researchers of economic instruments for biodiversity conservation point out, there is an urgent need to develop new tools for the conservation of biodiversity and ecosystem services. Despite numerous policy measures and tools developed during the long history of nature conservation, attempts have been ineffective in stopping biodiversity loss 7.

One of the instruments of state policy in the European Community is «state aid» to economic entities, the basic principles of which are defined in the EU-based Founding Agreement. The procedure for granting and criteria for assessing the eligibility of state aid in the field of environmental protection is set out in the EU Guidelines on State aid 
for environmental protection and energy 2014-2020. These recommendations establish special rules and regulations for state environmental aid in the EU member states and the countries of the European Free Trade Association (EFTA). The guidelines are reviewed every six to seven years, and the new rules were published on April 1, 2008, after the reform process for about two years.

The legal requirement to control the provision of state aid in Ukraine follows from a number of international obligations of Ukraine, in particular, the Association Agreement with the EU, which requires Ukraine during a certain transition period to implement a number of important measures for the introduction of a full-fledged control system that meets EU standards.

In accordance with the Law of Ukraine "On State Aid to Business Entities» (2014) 1, the Antimonopoly Committee of Ukraine (AMCU) has designated the authorized body for monitoring and control in the field of state aid in Ukraine. Since 2017, the Antimonopoly Committee should evaluate newly announced state support measures aimed at identifying state aid measures that are not compatible with the requirements of the new Law and bringing the current state aid measures in line with the Law. Thus, a national state aid control system will be brought in line with the EU state aid rules within a specified period.

Principles of state ecological policy in Ukraine and its rules of application are set forth in the Law of Ukraine "On the Basic Principles (Strategy) of the State Environmental Policy of Ukraine for the Period till 2020») of December 21, 2010 No. 2818-VI. This law provides for direct budget financing for the establishment of environmental monitoring systems, ensuring compliance with state environmental standards, and also provides support and appropriate compensation for the costs of economic entities that implement environmental projects or improve the state of the environment.

In particular, one of the important principles enshrined in the national environmental policy is to stimulate business entities to modernize production and reduce the negative impact on the natural environment.

In accordance with the provisions of the Law «On State Aid», criteria should be developed for the provision of state aid for the environmental protection. In pursuance of these provisions, the Antimonopoly Committee of Ukraine elaborated a draft Decree of the Cabinet of Ministers of Ukraine «On Approval of Criteria for Assessing the Validity of State Aid to Business Entities for the Environmental Protection» and was published it on its official website.

The draft Decree stipulates that state aid for environmental protection may be provided in any form specified in Article 4 of the Law of Ukraine "On State Aid to Business Entities", in particular, subsidies and grants; grants; tax breaks, deferrals or installments of taxes, fees or other obligatory payments, etc.

One of the types of state aid for the protection of the environment, proposed in the draft Resolution is state aid in the form of reduction or exemption from environmental taxes.

It should be noted that budget funds for environmental protection measures are used taking into account the List of activities related to environmental protection measures approved by the Resolution of the Cabinet of Ministers of Ukraine of 17.09.1996 No. 1147 and on the basis of the Procedure for Planning and Financing of Environmental Protection Measures, approved by the order of 
the Ministry of Ecology and Natural Resources of Ukraine dated June 12, 2015, No. 194 and registered with the Ministry of Justice of Ukraine on August 18, 2015 under No. 994/27439, where there is a clear definition of the customer of environmental protection measures.

The analysis of the legislative framework shows that the provisions set out in paragraph 11 of the draft Resolution ("State Aid in the form of reduction or exemption from environmental taxes") are not consistent with Article 48 of the Law of Ukraine "On Environmental Protection"3 and Article 4 of the Law of Ukraine "On state aid to economic entities"1, which stipulates granting of tax privileges, and not" exemption from environmental taxes “.

Environmental tax belongs to state taxes and proceeds from its payment are a source of financing for environmental and resource-saving measures (Article 47 of the Law on Environmental Protection3). The procedure for the enrollment of the environmental tax and its use is determined by the Budget Code of Ukraine2, and the procedure for the establishment and commissioning is the
Tax Code of Ukraine. Environmental tax is charged for the emission of pollutants into the atmosphere by stationary sources of pollution, the discharges of pollutants directly to water facilities and the disposal of waste (except for the placement of certain types (classes) of waste as secondary raw materials, placed in their own territories (objects) sub economic objects), that is, for pollution of the natural environment, has both a regulatory and a stimulating character for enterprises, and liberating or reducing it is inappropriate. Taking into account that financing of all types of protected areas in Ukraine and institutions and objects of the nature reserve fund is carried out at the expense of state and local budgets, the reduction of environmental tax revenues as a result of the release of business entities from its payment will lead to a catastrophically low level of support for the environmental protection land use and significant biodiversity loss.

A clear example of the results of reducing the support for environmental measures can be the analysis of the dynamics of funding for the nature reserve fund for the period $2010-20145$.

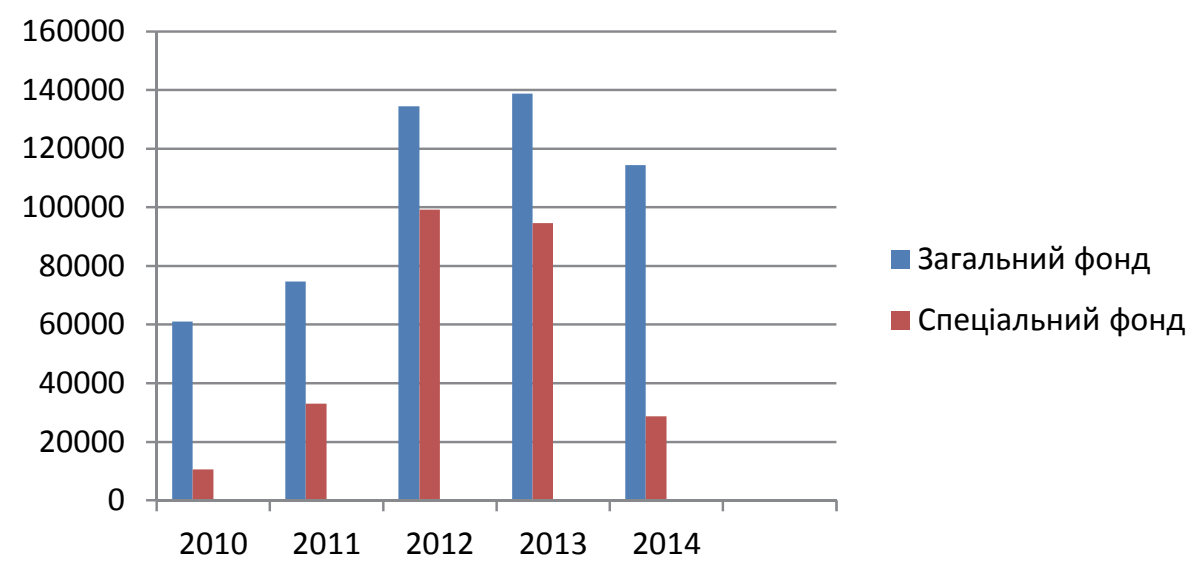

Fig. 1. Amount of allocation of funds for the maintenance and implementation of environmental protection measures in nationally designated PAs subordinated to the Ministry of Ecology and Natural Resources of Ukraine (ths. UAH).5 
According to the Law of Ukraine "On Amendments to the Law of Ukraine" On the State Budget of Ukraine for 2014 ", expenditures on the general fund amount to 114451.4 thousand UAH, or $87 \%$ of the allocations, which made it impossible for the proper functioning of the 41 establishments of the NFP.

The Law of Ukraine "On Amendments to the Tax Code of Ukraine and some laws of Ukraine (regarding tax reform), "the environmental tax (on fuel) has been transformed into an excise tax.

The Law of Ukraine "On Amendments to the Budget Code (on the reform of intergovernmental fiscal relations) increased the percentage of environmental tax from 35 to 80 percent to local budgets, and reduced to 65 percent to 20 percent of the state budget. The funds from the payment of the environmental tax were not credited to the special funds of the relevant budgets (State and local environmental funds), but to the general funds of the corresponding budgets. Thus, the environmental tax, with the adoption of such changes, ceased to be an integral part of the special funds of the state budget, as violated Art. 47 of the Law of Ukraine "On Environmental Protection", as well as he lost his function as a special purpose. The changes introduced indicate that the environmental tax funds are not tied to expenditures and will focus not only on programs of environmental protection measures of local importance, but also on measures of social and economic development.

Turning to the European experience of using such a political instrument of the state as the provision of state aid for the protection of the environment, it should be noted that the conservation of biodiversity is classified as a service of pan-European public interest. ${ }^{7}$ Environmental tax is the main regulatory ecolog- ical and economic instrument of public policy that meets the "polluter pays" principle. The introduction of a full exemption from environmental taxes may lead to distortions of competition and deprive the state of the regulatory instrument for environmental policy. The proposed public attention to the draft Decree needs to be substantially refined, brought in line with the current legislation and amended to exclude the exemption from environmental tax of economic entities in order to avoid worsening of the ecological state of watercourses in the country and as a result the loss of biodiversity.

\section{Conclusion.}

Based on the foregoing, it can be concluded that the introduction of the possibility of exempting economic entities from environmental tax can be attributed to a "harmful incentive" that may have a discriminatory character for competition and lead to a reduction in biodiversity due to deterioration of environmental land use. There is an urgent scientific and practical task to find alternative means of stimulating the implementation of environmental protection measures in the new market economic conditions.

\section{References}

1. Pro derjavnu Dopomogu sub'iektam hospodariuvannia. Zakon Ukrainy. ("About State Aid to the Economic Entities". Law of Uukraine). - Верховна Рада України; Закон від 01.07.2014 № 1555-VII. Retrieved from: http://zakon.rada.gov.ua/ laws/show/1555-18.

2. Budjetny Codex Ukrainy; //Vidomosty Verkhovnoiy Rady Ukrainy (Budget Codex of Ukraine) - 2010. - № 50-51. -p. 572. Retrieved from: http://zakon2.rada.gov.ua/ laws/show/2456-17. 
3. Zakon Ukrainy "Pro ohoronu navkolyshnioho seredovyshcha" of 25.06.1991 № 1264XII [The Law of Ukraine "On Environmental Protection"]. Retrieved from: http://zakon2.rada.gov.ua/laws/show/1264-12.

4. Pro pryrodno-zapovidny fond Ukrainy. Verhovna Rada Ukrainy; Zakon of 16.06.1992 № 2456-XII. Retrieved from: http://zakon2. rada.gov.ua/laws/show/2456-12.

5. Analysis of the status of the nature reserve fund of Ukraine. Ministry of Ecology and Natural Resources of Ukraine. Retrieved from: komekolog.rada.gov.ua/.

6. A report on the results of a study on state support for business entities in Ukraine Retrieved from: www.eupublicprocurement. org.ua.

7. Economic Instruments for Biodiversity and the EU State Aid Regulation . Elina Raitanen1, Jukka Similä, Kristian Siikavirta, Eeva Primmer. [Електронний ресурс] -Режим доступу: http://booksandjournals.brillonline.com/content/journals/10.1163/18760104-01001002.

\section{$* * *$}

\section{Демиденко Л.Г.}

ЗАКОНОДАВЧЕ РЕГУЛЮВАННЯ ДЕРЖАВНОЇ ДОПОМОГИ У ГАЛУЗІ ПРИОДОХОРОННОГО ЩЗЕМЛЕКОРИСТУВАННЯ ЯК ІНСТРУМЕНТ ДЕРЖАВНОї ПОЛІТИКИ

Проаналізовано нормативні документи, за якими економічні стимули можуть стати державною допомогою, визначено шляхи розробки європейської та начіональної політики, які дозволять виділення державної допомоги на охорону навколишнього середовища та природоохоронне землекористування, стимулювання збереження біорізноманіття на законній підставі.

Ключові слова: державна допомога, природоохоронне землекористування, екологічний податок, збереження біорізноманіття, природоохоронні території.

Демиденко Л.Г.

ЗАКОНОДАТЕЛЬНОЕ РЕГУЛИВАРОНИЕ ГОСУДАРСТВЕННОЙ ПОМОЩИ В СФЕРЕ ПРИОДООХРАННОГО ЗЕМЛЕПОЛЬЗОВАНИЯ КАК ИНСТРУМЕНТ ГОСУДАРСТВЕННОЙ ПОЛИТИКИ

В статье проанализировано нормативные документы, в соответствии $c$ которыми экономические стимулы могут стать государственной помощью, определено пути разработки европейской и национальной политики, которые позволяют выделение государственной помощи на охрану окружающей среды и природоохранное землепользование, стимулирование сохранения биоразнообразия на законных основаниях.

Ключевые слова: государственная помощь, природоохранное землепользование экологический налог, сохранение биоразнообразия, приодоохранные территории. 